\title{
Impact of Structure Related Firm Characteristics on Performance of Microfinance Institutions in Nakuru, Kenya
}

\author{
Zachary Kisengo $^{1}$, Simon Kipchumba ${ }^{2}$ \\ ${ }^{1}$ Egerton University, Faculty of Commerce, P.O. Box 13357-20100 Nakuru, Kenya \\ ${ }^{2}$ Egerton University, Faculty of Commerce, P.O. Box 13357-20100 Nakuru, Kenya
}

\begin{abstract}
Microfinance institutions are established to finance small enterprises, however they do not meet this. In spite of the importance of this sector, the provision and delivery of services has been below expectation. Literature suggests that structure related firm characteristics determine performance of microfinances but it is not clear to what extent. The objective of study was to examine the impact of structure related firm characteristics on the performance of the microfinance sector in Kenya. The study adopted correlational research design. A census was done on the 52 institutions registered with AMFI and operating in Nakuru. Primary data was collected using questionnaires. This was supplemented with secondary data. Data on firm characteristics and organizational performance was summarized using descriptive statistics. The relationship between structural firm characteristics and performance of MFIs was examined using correlation. The effect of structural firm characteristics on performance of microfinances was determined by regression analysis. Findings revealed that structural firm characteristics have a significant positive effect on performance of MFIs. It is recommended that practitioners address and nurture these characteristics to improve on performance of the sector.
\end{abstract}

Keywords: Firm Characteristic, Entrepreneurship, Microfinance, Organization, Performance

\section{Introduction}

The growing global concern about persistent stagnation and decline in economic growth, accompanied by chronic unemployment, poverty and its resultant social problem have led to increased search for strategies which can stimulate economic growth. One strategy that has been growing in importance is entrepreneurship. Both developed and developing countries have focused on this strategy. In almost all economies, small businesses are critical for sustained growth. They have been the means through which accelerated economic growth and rapid industrialization have been achieved (Arinaitwe, 2002).

Kenya has created conditions for private sector growth but is still held back by an inadequate financial system (Lafourcade et al., 2005). Various analyses (Sauser, 2005; Harris \& Gibson, 2006) have identified the challenges of the sector as lack of capital, inhibiting enabling environment and poor non-financial promotional programs. This means that it is difficult for the poor to elevate out of poverty due to lack of finance for their productive activities. About $60 \%$ of the population are poor and mostly out of the scope of formal banking services (Omino, 2005). The formal banking sector in Kenya over the years has regarded the informal sector as risky and not commercially viable. Therefore, new, innovative, and pro-poor modes of financing low-income households based on sound operating principles have been developed by the microfinance institutions.

Various business settings have specific and unique attributes that make them distinguishing. According to Golan et al., (2003) firm's resources and objectives summarized as firm characteristics, influence success and failures associated to performance of organizations. Firm characteristics refer to the enterprise and related variables which play an important role on the business success. These include structural, market and capital related variables. Structural firm characteristics include firm size, leverage, ownership dispersion, firm age, debt, corporate strategy (Wallace et al., 2004).

Daft (1995) defined performance as the evaluation of achievement of the company target. In business life, performance is a key term in the field of management, although it is not always explicitly stated. However, there is no universally accepted definition of performance hence interpreted in various ways (Foley \& Green 1989). Performance can be in the form of survival, profit, return on investment, sales growth, number of employees, happiness, reputation, and so on.

In as much as microfinance is seen as a possible solution to the financial problems of small and micro businesses, the capital needs of the businesses have not been adequately met suggesting there are factors affecting performance of microfinances. Strategic management literature further suggests that structural firm characteristics affect performance of organizations (Nugroho \& Miles, 2009).Although a number of researches (Aklilu, 2002) have been done on factors that contribute to performance of microfinances, little has been done to empirically determine the effect of structural firm characteristics on the performance of microfinance institutions particularly in Kenya. Wright (2001), notes that there is compelling evidence to support the contention that a significant majority entrepreneurship failure occurs because microfinance services are inadequate to meet the needs of the very clients they are claiming to serve. Theoretically there is a link between structure related firm characteristics and organizational performance. This study therefore sought to empirically examine the impact of structure related firm 


\section{International Journal of Science and Research (IJSR) \\ ISSN (Online): 2319-7064}

Index Copernicus Value (2013): 6.14 | Impact Factor (2015): 6.391

characteristics on the performance of the microfinance institutions Nakuru town.

\section{Literature Review}

\subsection{Structure Related Firm Characteristics}

Firm characteristics entail structure, market and capitalrelated variables. Structure-related variables include firm size, ownership and firm age. Market-related include industry type, market uncertainty and environment. Capitalrelated entail liquidity and capital intensity. Structural variables are thought to be fairly stable and constant over time (Wallace et al., 2004).

\subsubsection{Size of the Firm}

The size reflects how large an enterprise is in infrastructure and employment terms. McMahon (2001) found that enterprise size significantly linked to better business performance. Chen and Hambrick (1995) provide a summary and overview of the importance of firm size. Firm size has been shown to be related to industry-sunk costs, concentration, vertical integration, and overall industry profitability (Dean et al., 1998). Larger microfinances are more likely to have more layers of management, greater number of departments, increased specialization of skills and functions, greater formalization, greater centralization, and greater bureaucracy than smaller microfinances (Daft, 1995).

Based on these arguments, firm size is expected to be an important predictor of microfinance performance. One would expect that larger microfinances experience greater resistance to change and would require higher expenditures to implement and maintain (Kelly, 1992). Furthermore, many of the key elements of quality management already present to some extent in smaller microfinances, lower costs of implementing and maintaining. Larger microfinances may also find it more difficult to maintain an atmosphere of continuous improvement. Hence, maintaining an effective quality implementation is likely to be more difficult for larger than smaller microfinances.

The size of a firm is one of the major drivers of operational costs. Gonzalez (2007) points out large microfinances are more productive in terms of average cost per borrower and also have better write-off ratios. He also found that bigger microfinances are associated with smaller average costs making them more efficient.

The financial determinants of economies of scale occur due to size where large microfinances enjoy better interest and discount rates due to trading in large quantities. Large microfinances enjoy economies of scale and higher negotiation power over their clients and supplier (Singh \& Whittington, 1975). They have easy access to credit for investment and a range of human capital that is qualified. They are also likely to attain greater strategic diversification (Yang \& Chen, 2009). The hierarchy in small microfinances puts them in strategic position to counter the disadvantages arising from their size. They experience less agency problems and are more flexible in a changing environment.

\subsubsection{Age of the Firm}

Age of the firm refers to the length of time that a firm has existed, usually expressed in years. According to Usman and Zahid (2011), age related factors can be observed on three different levels: an old organization may have more customers which may drive economies of scale; higher average loan sizes resulting from repeat customers may improve the cost structure and more knowledge about customers may streamline processes.

Length time in operation may be associated with learning curve. Older firms most probably have learned much from their experiences than new comers. Kristiansen et al., (2003) found that length time in operation was significantly linked to business success. Many studies have found that an MFI's efficiency and profitability are strongly related to its age (Gonzalez, 2008). The large pool of customers with an old MFI and the resulting efficiency is therefore, likely to make it achieve a higher growth in outreach and higher AROA and financial self-sufficiency.

Microfinances at the early stage of operation experience difficulties in access to debt finance because of informational disparities. The longevity of the microfinance stays in operation, the more persistence to unpleasant economic circumstances (Chandler, 2009). Ngoc et al., (2009) supported the argument that younger MFIs face hardship and more costs in accessing external financing from lenders because of information asymmetry. Consequently there is hypothetical existence of a positive relationship between microfinance's age and performance.

\subsubsection{Ownership of the Firm}

Origin is the concept from which an enterprise develops from, founders or the place where it comes from. According to Smallbone et al., (1995), origin of enterprise in firms, where ownership and management were typically combined in one or more individuals and future goals for the business might be determined as much by personal lifestyle and family factors as by commercial considerations.

Duchesneau and Gartner (1990) found that lead entrepreneurs in successful firms were more likely to have been raised by entrepreneurial parents, to have had a broader business experience and more prior startup experience, and to believe that they had less control of their success in business, than unsuccessful entrepreneurs. They also found that lead entrepreneurs in successful firms worked long hours, had a personal investment in the firm, and were good communicators. Moreover, successful microfinances are those initiated with ambitious goals, and lead entrepreneurs have a clear and broad business idea (Duchesneau \& Gartner, 1990). Firms with more than one shareholder when set up were significantly more likely to survive (Westhead et al., 1995). Education and prior experience in business have been seen as critical success factors for microfinances (Yusuf 1995; Wijewardena \& Cooray, 1996).

Dietmar et al., (1998) point out that firm with limited liability possess development attributes than firm with unlimited liability. First, the separation of owner's affairs and business affairs increase the commitment of managers to the firm goals. Second, Publication of their financial 


\section{International Journal of Science and Research (IJSR) \\ ISSN (Online): 2319-7064}

Index Copernicus Value (2013): 6.14 | Impact Factor (2015): 6.391

statements makes corporation's openness for users to know the firm's status including their debt ratio and firm's assets. Cassar (2004) found out that lenders observe incorporation as a good indicator for firm's trustworthiness and commitment to operational laws. The study conducted by Coleman and Cohn (2000) and Fatoki and Asah (2011) evidenced presence of a positive association between legal formation and performance of MFIs.

Claessens et al., (2001) find that foreign microfinances have higher profits than domestic microfinances in developing economies. Berger et al., (2005) postulates that state-owned microfinances have poor long-term performance, but improve considerably after privatization. Other studies find that generally foreign-owned microfinances suffer disadvantages related to high monitoring costs and information asymmetries compared to local competitors in developing markets (Lensink \& Naaborg, 2007; Luo et al., 2009). Privately owned microfinances have also been assessed to be more profitable than their state owned (La Porta et al., 2002). They posit that public microfinances' low profitability is due to the fact that, rather than maximizing profits, they respond to a social mandate.

\subsection{Organizational Performance}

Organizational performance refers to the firm's success in the market, which may have different outcomes. Performance is a focal phenomenon in business studies; however it is also complex and multidimensional. It can be characterized as the firm's ability to create acceptable outcomes and actions (Reed et al., 2000). However, there is no universally accepted definition of performance which can be interpreted in many ways (Foley \& Green 1999). Hence, performance can have different forms, e.g. survival, profit; return on investment, sales growth, number of employees, happiness, reputation, etc.

Goldstein (1996) stated that determinants of microfinance performance can be grouped into two categories, namely internal and external factors. Internal determinants which are within the control of management can be broadly classified into financial statement and non-financial statement variables. Sudin (2004) stated that external factors are those factors that are considered to be beyond the control of the management include competition, regulation, concentration, market share, ownership, scarcity of capital, money supply, Interest rate spread, and inflation size.

There are various ways through which microfinance performance can be measured. European Central Bank (2010) report has categorized them in to three major categories which are traditional, economic and market based measures. The traditional measures are similar to those used by other firms which include ROA which is the net income for the year divided by the total assets and ROE which is the internal performance measure of shareholder's value. The economic measures of performance aim at assessing the economic results generated by the MFI from its economic assets. The market based measures depend on the way the capital market value the performance of firm as compared to its economic and accounting value.
The main measure of performance is through ratio analysis which has been identified as convenient and efficient method of assessment since it combines information from financial statements and comes up with numbers that are more easily interpreted, (Burkhardt, 2013). Financial measures are regarded as "lag" indicators of performance whereas Intellectual capital measures (like non-financial measures) are regarded as "lead" indicators since they are mainly intended to generate future earnings power (Kaplan \& Norton, 2001). While all future earnings are uncertain, it is greater for intellectual capital than for tangible assets. Traditionally, firms relied on their tangible assets to drive their performance and firm-level strategy.

The Kenyan financial sector is one of the broadest and most developed in sub-Saharan Africa, with 45 financial institutions, including 43 commercial banks and 2 mortgage finance companies (Omino, 2005). These banks make up Kenya's formal banking sector and serve 22.6 percent of Kenya's adult population, according to survey results published in early 2009. Non-bank financial institutions, including MFIs, savings and credit cooperatives, and mobile phone service providers serve another 17.9 percent of the population, bringing the total served by formal financial services to 40.5 percent. Another 26.8 percent of Kenyans rely on the informal financial sector, including NGOs, selfhelp groups, and individual unlicensed money lenders, and 32.7 percent of the population does not use any form of financial services (Omino, 2005).

\subsection{Structural Firm Characteristics and Organizational Performance}

The determinants of firm performance have long been of central interest to strategic management researchers (Rumelt et al., 1994). Performance is often defined simply in terms of output such as quantified objectives or profitability. Brumbach (in Armstrong, 2006) defines performance as both behavior and results. This covers the achievement of expected levels as well as objective setting and review. The underlying thought is to investigate this relationship bearing in mind that if the structural firm characteristic is appropriate, then the expected levels of output will be achieved (success) and vice versa for failure. Success and failure are taken as the two ends of the performance continuum.

Various scholars have tried to set out a clear definition of microfinance performance (Chu-Hua et.al., 2001), but this debate continues to date within the academic literature, more so regarding some aspects of terminology issues, analytical levels, and the conceptual basis for assessment. According to Ginsbert and Venkatraman (1985), there are three different levels of performance within micro finances. They are distinguished as the financial performance, business performance and organization effectiveness, although the latter has been subsequently known as organizational performance (Terziovski \& Samson, 2000). Performance is the key interest of every business manager or owner. The overall performance depends on strategic fit of firm characteristics and objectives. Organizational performance is measured by how relatively efficient a microfinance is in 


\section{International Journal of Science and Research (IJSR) \\ ISSN (Online): 2319-7064}

Index Copernicus Value (2013): 6.14 | Impact Factor (2015): 6.391

converting strategic assets, as defined by the resource-based view, into performance.

The search for an ideal or perfect structure is about as futile as trying to find the ideal canned improvement process to drop on MFIs. It depends on the microfinance's context and focus (vision, values, purpose), goals and priorities, skill and experience levels, culture; teams' effectiveness and so on; each is unique to any organization (Clemmer, 2006).

Empirical research and experience shows that the shape and characteristics of high performing MFI structures have a number of common features. First intense customer and market focus where systems, structures, processes, and innovations all aim at and flow of the market and customers. Field people and hands-on managers drive the MFI in daily contact with customers and partners. Next team-based where operational and improvement teams are used up, down and across. A multitude of operational teams manage whole systems or self-contained subsystems such as regions, branches, processes, and complete business units (DeVaro \& Kurtulus, 2006).

\section{Methodology}

\subsection{Research Design}

The relationship between structural firm characteristics and performance is best handled using correlation analysis as it is a joint relationship of the variables but not a causal relationship, where it showed the nature of the relationship between the research variables and the direction of the relationship (Mugenda, 2005). The data collected were both qualitative and quantitative in nature as it attempted to collect data from members of a population in order to determine the current status with respect to one or more variables. The design made it possible for the researcher to have a systematic collection and presentation of data thus determine the impact of structural firm characteristics on the performance of MFIs in Kenya.

\subsection{Target Population}

The population of this study entailed all the MFI operating within Nakuru town. There are 52 institutions offering microfinance services operating in Nakuru town (Nakuru County Profile, 2013).

\subsection{Study Design}

The study conducted a census on all the 52 microfinance institutionsregistered with Association of Microfinance Institution (AMFI) operating in Nakuru town.The number was considered small not to warrant sampling. Furthermore, it was convenient and affordable to obtain data from all the subjects under investigation.

\subsection{Data Collection}

Data regarding structural firm characteristics and organizational performance was accomplished through selfadministered questionnaires. This was administered to the relevant manager who provided the required information. The questionnaire was self-administered to enhance clarification of questions. Care was taken to afford the respondent independence and avoid researcher influence.

\subsection{Reliability and Validity}

Cronbach's alpha co-efficient was used to test for reliability of firm characteristics and performance instruments. The average Cronbach's alpha coefficient for the firm characteristics instrument was 0.805 and 0.777 for performance which is above the threshold of 0.7 which is considered acceptable (Sekaran, 2004).A pretest was conducted in order to increase the validity of the questionnaires. Consequently a test-retest approach method was used to further test the validity of the instruments. The design, took into consideration what should be measured and what should not be measured and to what extent hence explanation for relationship noticed.

\subsection{Data Analysis}

Researcher enlisted the code for the returned questionnaires and entered them into a table. The data gathered was analyzed using descriptive statistics which entailed means, percentages and standard deviation. To examine the relationship between firm characteristic and performance of MFI, Pearson product moment correlation coefficient was employed. To determine the effect of firm characteristics on performance of the MFIs, multiple regression analysis was used. The below multiple regression equation was developed:

$\mathrm{y}=\mathrm{a}+\mathrm{b}_{1} \mathrm{x}_{1}+\mathrm{b}_{2} \mathrm{x}_{2}+\mathrm{b}_{3} \mathrm{x}_{3}+\mathrm{e}$

Where;

$\mathrm{a}=$ constant

$\mathrm{x}_{1}=$ size of firm

$\mathrm{x}_{2}=$ age of firm

$\mathrm{x}_{3}=$ ownership of firm

$b_{1}-b_{3}=$ regression coefficients

$\mathrm{e}=$ error term

\section{Results and Discussion}

\subsection{Structure Related Firm Characteristics}

The structural firm characteristics that were studied include size, age and ownership. Information about the characteristics was collected, analyzed and then presented in tables.

\subsubsection{Size of the firm}

Data on size of the firm was analyzed in percentages and the results are presented in Table 4.1 below. 


\section{International Journal of Science and Research (IJSR) \\ ISSN (Online): 2319-7064}

Index Copernicus Value (2013): 6.14 | Impact Factor (2015): 6.391

Table 4.1: Size of the firm in percentages

\begin{tabular}{|c|c|c|c|c|c|}
\hline \multirow{2}{*}{ No. Of Branches } & Less than 5 & Btwn 5-10 & Btwn 11-20 & Btwn 21-30 & Above 30 \\
& 26.7 & 6.7 & 13.3 & 26.7 & 26.7 \\
\hline Networth of the firm '000 & Below 5 & 5 to 10 & Btwn 10-15 & Btwn 15-20 & Over 20 \\
000' & 0.0 & 13.3 & 0.0 & 0.0 & 86.7 \\
\hline \multirow{2}{*}{ Average Loan Size '000' } & Below 20 & $20-40$ & $40-60$ & $60-80$ & Above 80 \\
& 0.0 & 26.7 & 33.3 & 20.0 & 20.0 \\
\hline No of employees & Below 100 & $100-200$ & $100-300$ & $300-400$ & Above 400 \\
& 40.0 & 20.0 & 0.0 & 6.7 & 33.3 \\
\hline
\end{tabular}

As shown in Table 4.1 over $50 \%$ of the MFIs have more than 50 branches of which $27 \%$ have over 30 branches. None of the MFIs has a net worth below 5 million. Most MFIs have a net worth of over 20 million which is a massive $86 \%$. Table 4.1 illustrates that none of the MFIs awards loans below 20 thousand. Moreover there are $20 \%$ of the MFIs who award loans above 80 thousand. On average most MFIs give loans between 40-60 thousands (33\%).Most of the MFI (40\%) have below 100 employees. Further $33 \%$ of the MFIs, have over 400 employees.

\subsubsection{Age of the firm}

Data on age of the firm was analyzed in percentages and the results are presented in Table 4.2 below.

Table 4.2: Age of the firm in percentages

\begin{tabular}{|c|c|c|c|c|c|}
\hline Years MFI has been in & Below 10 yrs & $10-20$ Yrs & $21-30$ Yrs & $31-40$ Yrs & Above 41 Yrs \\
operation & 46.7 & 33.3 & 13.3 & 0.0 & 6.7 \\
\hline No of CEOs the firm has & Less than 2 & Btwn 2-4 & Btwn 5-7 & Btwn 8-10 & Above 10 \\
had since inception & 37.8 & 48.9 & 13.3 & 0.0 & 0.0 \\
\hline
\end{tabular}

Table 4.2 shows that only $7 \%$ of the MFIs have operated for over 40years with none having operated between 31 and 40 years. Most of the MFIs (47\%) have operated for less than 10 years. Most of the MFIs (49\%) have had between 3 and 6 CEOs since inception. Further there is no microfinance that has had more than 9 CEOs. Majority of the MFIs (33\%) have the C.E.O.'s tenure running between 6-8years.

\subsubsection{Ownership of the firm}

Data on ownership of the firms was analyzed in percentages and the results are presented in Table 4.3 below.

Table 4.3: Structure related firm characteristics in percentages

\begin{tabular}{|l|c|c|c|c|c|}
\hline \multirow{2}{*}{ The MFI's legal structure } & NGOs & Cooperatives & Credit Unions & Non bank & Banks \\
& 0.0 & 0.0 & 6.7 & 40.0 & 53.3 \\
\hline \multirow{2}{*}{ CEOs tenure in office(yrs) } & Below 2 & Btwn 2-4 & Btwn 4-6 & Btwn 6-8 & Above 8 \\
& 13.3 & 26.7 & 20.0 & 33.3 & 6.7 \\
\hline \% of manag't board comprising & Below 20 & Btwn 20-40 & $40-60$ & $60-80$ & Above 80 \\
professionals & 0.0 & 0.0 & 6.7 & 0.0 & 93.3 \\
\hline
\end{tabular}

It can be seen in Table 4.1 that most MFIs (53\%) also operate as banks. However none of the microfinances operates as a cooperative or an NGO. Majority of the microfinances are locally fully owned $(93 \%)$ while a few have majority local shareholders $(7 \%)$. However none has equal foreign and local ownership or majority foreign ownership. Majority of the MFIs (33\%) have the C.E.O.'s tenure running between 6-8years. The management board of the MFIs (93\%) comprises of over $80 \%$ professionals. There is no MFI having below $40 \%$ professionals in the management board.

Table 4.4 Performance level of MFIs

\begin{tabular}{|l|c|c|c|c|c|}
\hline & $\begin{array}{c}\text { Very much } \\
\text { decreased (\%) }\end{array}$ & $\begin{array}{c}\text { Moderately } \\
\text { decreased }(\%)\end{array}$ & $\begin{array}{c}\text { Not changed } \\
(\%)\end{array}$ & $\begin{array}{c}\text { Moderately } \\
\text { increased }(\%)\end{array}$ & $\begin{array}{c}\text { Very much increased } \\
(\%)\end{array}$ \\
\hline Changes in branch network & 0.0 & 0.0 & 6.7 & 60.0 & 33.3 \\
\hline Changes in number of clients & 6.7 & 0.0 & 0.0 & 40.0 & 53.3 \\
\hline Changes in loans recovered & 0.0 & 6.7 & 13.3 & 73.3 & 6.7 \\
\hline Changes in loans volume & 6.7 & 0.0 & 0.0 & 46.7 & 46.7 \\
\hline Changes in funding from donors & 20.0 & 13.3 & 20.0 & 33.3 & 13.3 \\
\hline Changes in financial surplus & 0.0 & 6.7 & 20.0 & 46.7 & 26.7 \\
\hline Changes in the firm's assets & 0.0 & 6.7 & 6.7 & 66.7 & 20.0 \\
\hline Anticipation of funding short fall & 77.8 & 2.2 & 0.0 & 6.7 & 13.3 \\
\hline Changes in the firm's liquidity crisis & 86.7 & 0.0 & 0.0 & 13.3 & 0.0 \\
\hline Firm experienced positive cash flow & 6.7 & 0.0 & 6.7 & 40.0 & 46.7 \\
\hline loan processing period & 6.7 & 0.0 & 0.0 & 20.0 & \\
\hline
\end{tabular}

\subsection{Organizational Performance}

Most microfinances have positive ROA, meaning they are making profits. To establish the level of organizational performance of the microfinances, respondents were asked to indicate to what level the aspects of performance had changed in their organization in the last three years. The data was coded in Likert scale of 1 to 5 . Averages for each item were calculated and then analyzed using percentages. This is presented in Table 4.4 


\section{International Journal of Science and Research (IJSR) \\ ISSN (Online): 2319-7064}

Index Copernicus Value (2013): 6.14 | Impact Factor (2015): 6.391

From Table 4.4, loans volumes have moderately and very much increased for most MFIs giving an average of $46 \%$ in each case. Loans recovered for most of the MFIs have moderately increased $(73 \%)$. Funding from donors seems inconsistent with no major dominant trend in change though it seems to have moderately increased. The client level has very much increased $(53.3 \%)$ for most microfinances with few having moderately increased. Financial surplus have moderately increased $(46.7 \%)$ for the MFIs with others having very much increased. Table 4.4 indicates that MFIs have very much increased in improving loan processing period. The microfinances have moderately increased in opening up new branches as well as acquiring assets. There is very much decrease in anticipation of funding shortfall and changes in liquidity crisis. These firms have also enjoyed improved positive cash flow with $47 \%$ of them having very much increased not forgetting the $40 \%$ that have moderately increased.

\subsection{Structural Firm Characteristic and Organizational Performance}

The study examined the relationship between the aspects of structural firm characteristics and performance. The hypothesis sought to determine the effect of structure related firm characteristics on organizational performance. Analysis was done using Pearson product moment correlation. The results are presented in Table 4.5

Table 4.5: Structure Related Firm Characteristic and Performance

\begin{tabular}{|c|c|c|c|c|c|}
\hline & & Firm size & Ownership & Firm age & organizational performance \\
\hline \multirow[t]{3}{*}{ Firm size } & Pearson Correlation & 1 & -.292 & $-.443 * *$ & $.625^{* * *}$ \\
\hline & Sig. (2-tailed) & & .052 & .002 & .004 \\
\hline & $\mathrm{N}$ & 49 & 49 & 49 & 49 \\
\hline \multirow[t]{3}{*}{ Ownership } & Pearson Correlation & -.292 & 1 & $.530 * *$ & $.428^{*}$ \\
\hline & Sig. (2-tailed) & .052 & & .000 & .028 \\
\hline & $\mathrm{N}$ & 49 & 49 & 49 & 49 \\
\hline \multirow[t]{3}{*}{ Firm age } & Pearson Correlation & $-.443 * *$ & $.530 * *$ & 1 & .273 \\
\hline & Sig. (2-tailed) & .002 & .000 & & .035 \\
\hline & $\mathrm{N}$ & 49 & 49 & 49 & 49 \\
\hline \multirow{3}{*}{$\begin{array}{c}\text { Organizational } \\
\text { performance }\end{array}$} & Pearson Correlation & $.625^{* *}$ & $.428^{*}$ & .273 & 1 \\
\hline & Sig. (2-tailed) & .004 & .028 & .035 & \\
\hline & $\mathrm{N}$ & 49 & 49 & 49 & 49 \\
\hline
\end{tabular}

From Table 4.5, the results reveal an r-value of .625 indicating a strong relationship between firm size and organizational performance. Moreover this relationship is positive. Hypothesis states that a relationship exists between firm size and performance. The p value (.004) is below .05 thus we accept the alternative hypothesis and conclude that there is sufficient evidence, at $5 \%$ level of significance, that there is a strong positive relationship between firm size and organizational performance of MFIs. On the basis of these statistical findings it was found that firm size had significant positive effect on organizational performance of MFIs. The results are consistent with various studies conducted by Usman and Zahid (2011) and Gonzalez (2008) who found that there was positive relationship between firm size and performance.

Results in table above indicate an r-value of .428 indicating moderate relationship between ownership and organizational performance. Moreover this relationship is positive. Hypothesis states that a relationship exists between ownership and performance. The p value (.028) is below .05 thus we accept the alternative hypothesis and conclude that there is sufficient evidence, at 5\% level of significance, that there is moderate positive relationship between ownership and organizational performance of MFIs. On the basis of these statistical findings it was found that ownership has a significant positive effect on organizational performance of MFIs. The results support earlier findings by Usman and Zahid (2011), Datta et al., (1991) and Daft (1995) who found that there was positive relationship between ownership and organizational performance.
As shown in Table 4.5, we have an r-value of .273 suggesting a weak relationship between firm age and organizational performance. However this relationship is positive. Hypothesis states that a relationship exists between firm age and performance. The $p$ value (.035) is below .05 thus we accept the alternative hypothesis and conclude that there is sufficient evidence, at $5 \%$ level of significance, that there is weak positive relationship between firm age and organizational performance of MFIs. On the basis of these statistical findings it was found that firm age have significant positive effect on organizational performance of MFIs. The findings are consistent with earlier works by McMahon (2001) Kristiansen et.al (2003) who found the existence of a positive relationship between firm age and organizational performance.

\subsection{Effect of Firm Characteristics on Organizational Performance}

The study sought to determine the effect of structure related on organizational performance of the microfinance sector. Regression analysis was conducted between the independent variables and dependent variables in the study. To determine the effect of structure related firm characteristics on organizational performance of micro finances, multiple regression was used to test this hypothesis as presented in Table 4.6 and Table 4.7.

The model summary in Table 4.6 has $R$ value of 0.641 indicating a moderate positive relationship between firm characteristics and organizational performance of microfinances. The $\mathrm{R}$ squared value $\left(\mathrm{R}^{2}\right)$ is 0.411 indicating that $41.1 \%$ variation in the dependent variable 


\section{International Journal of Science and Research (IJSR) \\ ISSN (Online): 2319-7064}

Index Copernicus Value (2013): 6.14 | Impact Factor (2015): 6.391

(organizational performance) is explained by the independent variables (firm characteristics).

Table 4.6: Model Summary

\begin{tabular}{|c|c|c|c|c|}
\hline Model & $\mathrm{R}$ & R Square & $\begin{array}{c}\text { Adjusted R } \\
\text { Square }\end{array}$ & $\begin{array}{c}\text { Std. Error of the } \\
\text { Estimate }\end{array}$ \\
\hline 1 & $.641^{\mathrm{a}}$ & 0.411 & 0.381 & 0.4576 \\
\hline
\end{tabular}

a. Predictors: (Constant), capital related, structure related, market related

Table 4.7: Full Regression Model

\begin{tabular}{|c|c|c|c|c|c|c|}
\hline \multirow{2}{*}{ Model } & \multicolumn{2}{|c|}{$\begin{array}{c}\text { Unstandardized } \\
\text { Coefficients }\end{array}$} & $\begin{array}{c}\text { Standardized } \\
\text { Coefficients }\end{array}$ & \multirow{2}{*}{ T } & \multirow{2}{*}{ Sig. } \\
\cline { 2 - 7 } & B & Std. Error & Beta & & \\
\hline \multirow{2}{*}{} & (Constant) & 3.72 & 0.698 & & 5.326 & 0 \\
\hline & Firm size & 0.314 & 0.1 & 0.463 & 3.155 & 0.003 \\
\cline { 2 - 7 } 1 & Ownership & 0.454 & 0.193 & 0.365 & 2.353 & 0.024 \\
\cline { 2 - 7 } & Firm age & 0.166 & 0.084 & 0.326 & 1.97 & 0.046 \\
\hline
\end{tabular}

a. Dependent Variable: organizational performance

\begin{tabular}{|c|c|c|c|c|}
\hline Model & R & R Square & $\begin{array}{c}\text { Adjusted R } \\
\text { Square }\end{array}$ & $\begin{array}{c}\text { Std. Error of } \\
\text { the Estimate }\end{array}$ \\
\hline 1 & $.641^{\mathrm{a}}$ & 0.411 & 0.381 & 0.4576 \\
\hline
\end{tabular}

a. Predictors: (Constant), capital related, structure related, market related

Table 4.7: Full Regression Model

\begin{tabular}{|c|c|c|c|c|c|c|}
\hline \multirow{2}{*}{ Model } & \multicolumn{2}{|c|}{$\begin{array}{c}\text { Unstandardized } \\
\text { Coefficients }\end{array}$} & $\begin{array}{c}\text { Standardized } \\
\text { Coefficients }\end{array}$ & \multirow{2}{*}{ T } & \multirow{2}{*}{ Sig. } \\
\cline { 3 - 7 } & B & $\begin{array}{c}\text { Std. } \\
\text { Error }\end{array}$ & Beta & & \\
\hline \multirow{4}{*}{1} & (Constant) & 3.72 & 0.698 & & 5.326 & 0 \\
\cline { 2 - 7 } & Firm size & 0.314 & 0.1 & 0.463 & 3.155 & 0.003 \\
\cline { 2 - 7 } & Ownership & 0.454 & 0.193 & 0.365 & 2.353 & 0.024 \\
\cline { 2 - 7 } & Firm age & 0.166 & 0.084 & 0.326 & 1.97 & 0.046 \\
\hline
\end{tabular}

a. Dependent Variable: organizational performance

From the full regression model in Table 4.7, we obtain the regression equation. Using the unstandardized beta coefficients, the following regression equation was developed.

$\mathrm{Y}=3.72+0.31 \mathrm{X}_{1}+0.45 \mathrm{X}_{2}+0.17 \mathrm{X}_{3}+\varepsilon$

On the basis of the beta and significance values, structure related firm characteristics namely; firm size $(\beta=0.314$, $\mathrm{P}=0.003)$, ownership $(\beta=0.454, \mathrm{P}=0.024)$, firm age $(\beta$ $=0.166, P=0.046$ ) were found to significantly influence performance of microfinances. This means that the three independent variables contributed significantly to the model and thus the alternative hypothesis that firm characteristics have significant influence on performance of the MFIs in Nakuru was accepted. From the analysis, it is noted that a unit change in firm size had greatest impact on performance of the MFIs while firm age had the least.

The standardized beta coefficients give a measure of the influence of each variable to the model. Regarding the inference of structure related firm characteristics on performance, the study revealed that firm size had a greater influence on performance (Beta $=0.463$ ), followed by ownership $($ Beta $=0.365)$, finally firm age had the least inference on performance $($ Beta $=0.326)$.
These results are consistent with research findings done earlier by Usman and Zahid (2011), McMahon (2001) and Kristiansen et.al (2003) who established that structure related firm characteristics comprise the basis of determinants of organizational performance. These findings established that the three aspects are complementary in the sense that they jointly influence performance level of microfinances.

\section{Conclusion}

The general finding of the study confirms that all the three dimension of structure related firm characteristics will have influence on the performance of the microfinance sector. The size and age of microfinances have a positive relationship with performance of microfinance. The study therefore provides a solution to our problem which sought to determine the effect of structure related firm characteristics on organizational performance. From the results it can be concluded that structure related firm characteristics account for $41.1 \%$ variation in organizational performance of firms in the microfinance sector.The other remaining percentage could be explained by factors that are out of scope of this study. Conclusively, the results of the study show that structure related firm characteristics have a significant effect on organizational performance of microfinances.

The study reveals that there is a positive relationship between structure related firm characteristics and organizational performance of microfinances. From the findings, it is recommended that stakeholders in the microfinance sector should focus most of the resources on establishment of strong background, so that they can reap from their investments. Therefore there should be a continuous effort to enhance awareness and prosperity of structure related firm characteristics since firms collapse, as a result of poor management of resources i.e. structure based firm characteristics. Therefore potential investors should consider large microfinances, established (old) microfinances, as well as stable ownership so to reap maximum returns. From the findings, it can be recommended that MFIs should put in place established resources so as to have competitive advantage in the industry.

The study focused on the effect of structure related firm characteristics on performance of microfinance institutions. The findings suggest that organizational performance of MFIs is explained at $41 \%$ by structure related firm characteristics. This gives room for further studies to establish other casual relationships. It will be of interest for researchers to map structure related firm characteristics ratings with actual financial performance. A future research can also be done by making an inquisitive study into the financial prowess of the firms. Further enlargement of the scope of study to a larger geographical area would also have a significant increment to the value of this research. Therefore research could be done on MFIs in other regions or a similar study in other sectors.

\section{References}

[1] Aklilu, Y. (2002). The Importance of Micro Finance Institutions in Developing Economies: Country 


\section{International Journal of Science and Research (IJSR) \\ ISSN (Online): 2319-7064}

Index Copernicus Value (2013): 6.14 | Impact Factor (2015): 6.391

Experience and Policy Implications to Ethiopia", NBE Staff Working Paper, ERD/SWP/005/2002.

[2] Arinaitwe, J. K. (2006). Factors Constraining the Growth and Survival of Small Scale Businesses. A Developing Countries Analysis. Journal of American Academy of Business, Cambridge, 8(2), 167-178.

[3] Cassar, A., Crowley, L. and Wydick, B. (2007). The effect of social capital on group loan repayment: evidence from field experiments, Economic Journal, 117, 85-106.

[4] Chandler, J. G. (2009). Marketing tactics of selected small firms in the East London CBD area. South Africa: University of South Africa.

[5] Claessens, S., Demirguc,-Kunt, A. and Huizinga, H. 2001. How does foreign entry affect domestic banking markets? Journal of Banking and Finance, 25(5), 891-911.

[6] Daft, R.L. (1995). Organization Theory and Design, 5th Edition. West Publishing Company, Minneapolis, St. Paul, MN.

[7] DeVaro, J. and Kurtulus, F. (2006). What Types of Organizations Benefit from Team Production, and How Do They Benefit? Articles \& Chapters. Paper 111.

[8] Duchesneau, D. \& W. Gartner. (1990). A profile of new venture success and failure in an emerging industry. Journal of Business Venturing, 5 (5), 297-312.

[9] Foley, P., \& Green, H. (1989). Small business success. London: Chapman.

[10] Ginsbert, A. \& Venkatraman, N. (1995). Contingency perspectives on organizational strategy: a critical review of the empirical research. Academy of Management Review, 5, 25-39.

[11] Golan, E.; Krissoff, B.; Kuchler, F. F.; Nelson, K.; Price, G.; \& Kelvin L. (2003). Traceability in the US food supply chain: dead end or superhighway? In Choices Vol. 2nd quarter.

[12] Kelly, K. (1992). Quality: small and midsize companies seize the challenge - not a moment too soon. Business Week 11, 66-69.

[13] La Porta, R., de-Silanes, F.L. and Shleifer, A. 2006. What works in security laws, Journal of Finance, 61(1), 1-32.

[14] Lafourcade, I.; Mwangi, J. \& Brown, C. (2005). Overview of the Outreach and Financial Performance of Microfinance Institutions in Africa. Nairobi: UON.

[15]Lensink, R. and Naaborg, I. 2007. Does foreign ownership foster bank performance? Applied Financial Economics, 17(11), 881-885.

[16] Mugenda, O. M. \& Mugenda, A.G. (2005).Research Methods, Quantities and qualitative approaches, Act press Nairobi.

[17] Nugroho, Y. \& Miles, I. (2009). Microfinance and Innovation. Global Review of Innovation Intelligence and Policy Studies. MIoIR University of Manchester.

[18] Omino, G. (2005). Regulation and Supervision of Microfinance Institutions in Kenya. Central Bank of Kenya. Essay on Regulation Supervision Series.

[19] Reed R., Lemak D.J. \& Mero N.P. (2000). Total quality management and sustainable competitive advantage. Journal of Quality Management, 5 (1) 5-26.

[20] Rumelt, R.P; Schendel, D.E; \& Teece D.J. (1994). Fundamental Issues in Strategy. Harvard Business School Press: Boston, MA.
[21] Sauser, W.I. (2005). Starting Your Own Business? Prepare for Success. SAM Management in Practice, 3(1), 1-4.

[22] Sekaran, U. (2004). Research Methods for Business: A Skill Building Approach. Kundli: John Willey and Sons.

[23] Usman, G \& Zahid, M. (2011). Factors Influencing Performance Of Microfinance Firms In Pakistan: Focus On Market Orientation International. Journal of Academic Research 3(5).

[24] Westhead, P. (1995). Survival and employment growth contrasts between types of owner managed high technology firms. Entrepreneurship Theory \& Practice, 20 (1), 5-28.

[25] Wijewardena, H. \& S. Cooray (1996). Factors contributing to the growth of small manufacturing firms: perceptions on Japanese owner/managers. Journal of Enterprising Culture, 4 (4), 351-361.

[26] Wright G. (2001), Microfinance systems: Designing Quality Financial Services for the poor, Zed books Ltd. London.

[27] Yusuf, A. (1995). Critical success factors for small business: perceptions of South Pacific entrepreneurs. Journal of Small Business Management, 33 (2), 68-73.

\section{Author Profile}

Zachary Muhindi Kisengo is an MBA (Strategic Management) graduate from Egerton University and B.Ed Science (MathematicsStatistics) from Egerton University. Kenya. He currently works as private management consultant in Kenya .He previously served in the Ministry of Devolution and Planning, State Department of Planning in Kenya and also with East African Breweries Ltd, Nairobi.

Simon Kibet Kipchumba is a Ph.D. Management (Higher Educational Management) graduate from Nanjing Agricultural University, China. and MBA from Egerton University. He currently lectures at Egerton University. He previously worked as a registrar at Kabarak University, Kenya. 